\title{
Response of Four Lemon (Citrus limon L. Burm) Cultivars Cultured in vitro to BAP, KIN and 2,4- D Combinations
}

\author{
Abdul Mohsin Radah Obiad Al Sayed, Magdi Ali Ahmed Mousa and Ahmed Abdullah Said \\ Bakhashwain
}

\author{
Department of Arid Land Agriculture Faculty of Metrology, Environment and Arid Land \\ Agriculture, King Abdulaziz University, Jeddah, Saudi Arabia \\ Vegetables Department, Faculty of Agriculture, Assiut University, Egypt
}

\begin{abstract}
The present study was carried out in the lab. of plant tissue culture at King Abdulaziz University to test the response of four lemon cultivars to micro-propagation using BAP, Kin and 2,4- D combinations. The used explants in this study were intermodal segments and collected from the one year old lemon seedlings which obtained from the Citrus Research Center, Najran, Saudi Arabia. The experiments were laid out in a split plot design using 4 replicates. The results revealed that there were significant differences due to genotypic and growth regulators effects and their interaction for all measured parameters except no of days to buds sprouting. Explants of 'Shehri' registered maximum values of no. of days to buds sprouting with $0.5 \mathrm{mg} / \mathrm{l}^{-1} \mathrm{Kin}+0.5 \mathrm{mg} / \mathrm{l}^{-1} 2,4-\mathrm{D}, \%$ sprouted buds with $0.5 \mathrm{mg} / \mathrm{l}^{-1}$ BAP, $\%$ dead shootlets with $2 \mathrm{mg} / \mathrm{l}^{-1}$ BAP $+0.5 \mathrm{mg} / \mathrm{l}^{-1} 2-, 4-\mathrm{D}$ and length of primary shoots $(\mathrm{mm}) 1 \mathrm{mg} / \mathrm{l}^{-1} \mathrm{BAP}+0.5 \mathrm{mg} / \mathrm{l}^{-1} 2-, 4-\mathrm{D}$. Shoots of 'AlnEurka' formed the highest no. of leaves with $0.5 \mathrm{mg} / \mathrm{l}^{-1} \mathrm{BAP}+1 \mathrm{mg} / \mathrm{l}^{-1} 2-, 4-\mathrm{D}$. Low responses were observed for explants from 'Shaary', 'Banzahir' and 'Aln-Eurka' on culture medium supplemented with high concentration of BAP alone or with combination of 2,4- D. There were observed no sprouted buds for explants of 'Shehri' on culture medium complemented with high concentrations of Kin in combinations with 2,4- D. Lemon explants were successfully in vitro propagated using intermodal segments and combinations of BAP, Kin and 2,4- D at low concentrations.
\end{abstract}

Keywords: Lemon, growth regulators, shooting, BAP, Kin, 2,4- D.

\section{Introduction}

Citrus is the third most important fruit crop in Saudi Arabia with an estimated production of 99019 ton from 11029 ha area during 2013. The cultivated area of lemon was reduced by $27.57 \%$ and the production by $31.23 \%$ since
2009 (total production of 143685 ton from 15216 ha area) (Saudi Ministry of Agriculture, 2014). The saline water and soil, climate change, limited number of cultivars and propagation methods may be responsible for the significant reduction in lemon production 
and cultivated area in Saudi Arabia. For instance, the conventional propagation methods is limited on the season and provide specific plant parts, as well as these methods do not guarantee the production of large quantities of lemon trees corresponding to the mother throughout the year (Al-Taha, 2009). Lemon, (Citrus limon L. Burm) (family Rutaceae) is a commercially important crop in the tropical and subtropical regions. Its nutrition such as juicy, acidic, and flavorful is the most widely used citrus fruit worldwide. Expansion of existing lemon plantation or the establishment of new large-scale ones is faced with many difficulties. Improvement of citrus by conventional method is hampered by polyembryony, sexual incompatibility and male or female sterility (Grosser, et al., 2007). The most important of these difficulties is the limited supply of trees of commercially desirable cultivars to meet growers need throughout the year. Therefore, the need for developing new methods of propagation is critically vital. To solve this problem in Saudi Arabia tissue culture techniques should employed to find new methods of clonal multiplication of desired cultivars. Micropropagation is the true-to-type propagation of a selected genotype using in vitro culture techniques. Nehra and Kartha, (1994) reported that the technology in vitro culture offers advantages over conventional methods of propagation for a rapid and largescale multiplication of important plants under in vitro conditions irrespective of season with conservation of space and time. Moreover, provides rapid multiplication of selected superior varieties, valid and rapid tool for studying the behavior of plants in response to salt stress and improve citrus against different a salt stress through exploiting somaclonal variations (Shiyab, et al., 2003 and Montoliu, et al., 2009). Different protocols of regeneration using various techniques and explants, including somatic embryogenesis and organogenesis have been reported for various citrus species (Al-Taha, 2009; Jajoo, 2010; Lombardo, et al., 2012). The presented work aims to develop an in vitro protocol for the rapid and efficient micropropagation for lemon cultivars, to help overcome the inadequacies of the current conventional propagation methods.

\section{Materials and Methods}

\subsection{Plant Materials}

This study was conducted at the lab of plant tissue culture, Department of Arid Land Agriculture, Faculty of Meteorology, Environment and Arid Land Agriculture, King Abdul Aziz University. The presented research was designed to test the response of four genetically distanced lemon cultivars (Citrus limon L. Burm) to micropropagation using nodal segments explants. The lemon cultivars were Citrus limon cv (Shehri), Citrus limon cv (Banzahir), Citrus limon cv (Shaary) and Citrus limon cv (Aln-Eurka). The one-year-old lemon seedlings were obtained from the Citrus Research Center, Najran, Saudi Arabia.

\subsection{Preparation of nodal segments}

The healthy, soft and juvenile branches of the four lemon cultivars were used for in vitro nodal segments. The nodal segments were collected from newly formed lateral branches on the one year old lemon seedlings. The attached leaves were removed. The branches were divided into pieces of $10 \mathrm{~cm}$ intervals, then washed thoroughly under running tap water for $30 \mathrm{~min}$. The $10 \mathrm{~cm}$ shoots were divided into $1-1.5 \mathrm{~cm}$ nodal segments as described by Spripaoraya et al. (2003). The nodal segments were sterilized as following: a) washed in running tap water for $30 \mathrm{~min}, \mathrm{~b}$ )surface sterilized with $70 \%$ ethanol for 1 to 2 minutes, d) dipped in $15 \%$ sodium hypochlorite $(\mathrm{NaHCl})$ solution containing one drop of Tween-20 for 10 min and e) rinsed 4 times with sterilized distilled water each of $5 \mathrm{~min}$. The steps from $b$ to e were 
conducted in sterilized conditions under the laminar air flow hood.

\subsection{Growth regulators treatments}

Sterilized explants of the four lemon cultivars were cultured on MS media supplemented with the following concentrations of BAP, 2,4$\mathrm{D}$ and Kin:

BAP treatments: $0.5 \mathrm{mgl}^{-1}, 1.0 \mathrm{mgl}^{-1}, 1.5$ $\mathrm{mgl}^{-1}$ and $2.0 \mathrm{mgl}^{-1}$; Kin treatments: $0.5 \mathrm{mgl}^{-}$ 1, $1.0 \mathrm{mgl}^{-1}, 1.5 \mathrm{mgl}^{-1}$ and $2.0 \mathrm{mgl}^{-1}$; BAP + 2,4-D Combinations Treatments: BAP 0.5 $\mathrm{mgl}^{-1}+2.4-\mathrm{D} 0.5 \mathrm{mgl}^{-1}$, BAP $0.5 \mathrm{mgl}^{-1}+2.4-$ D $1 \mathrm{mgl}^{-1}$, BAP $1 \mathrm{mgl}^{-1}+2.4-\mathrm{D} 0.5 \mathrm{mgl}^{-1}$, BAP $1 \mathrm{mgl}^{-1}+2.4-\mathrm{D} 1 \mathrm{mgl}^{-1}$, BAP $2 \mathrm{mgl}^{-1}+$ 2.4- D $0.5 \mathrm{mgl}^{-1}$ and BAP $2 \mathrm{mgl}^{-1}+2.4-\mathrm{D} 1.0$ $\mathrm{mgl}^{-1}$; Kin + 2,4-D Combinations Treatments: Kin $0.5 \mathrm{mgl}^{-1}+2.4-\mathrm{D} 0.5 \mathrm{mgl}^{-1}$, Kin $0.5 \mathrm{mgl}^{-1}+2.4-\mathrm{D} 1.0 \mathrm{mgl}^{-1}$, Kin $1 \mathrm{mgl}^{-1}+$ 2.4- D $0.5 \mathrm{mgl}^{-1}$, Kin $1 \mathrm{mgl}^{-1}+2.4-\mathrm{D} 1.0 \mathrm{mgl}^{-}$ ${ }^{1}$, Kin $2 \mathrm{mgl}^{-1}+2.4-\mathrm{D} 0 . \mathrm{mgl}^{-1}$ and Kin $2 \mathrm{mgl}^{-1}$ $+2.4-\mathrm{D} 1.0 \mathrm{mgl}^{-1}$. The experiment was conducted in a split plot design with 4 replications. The cultured test tubes were incubated under controlled environments with 2500 lux light intensity at temperature of $25 \pm 2^{\circ} \mathrm{C}$ for 16 hours photoperiod.

\subsection{Assessed parameters}

The response of lemon cultivars to in vitro shoot tip and nodal segments were assessed as: no. of days to bud sprouting, percentage of sprouted buds, percentage of dead shootlets, average length of primary shoots, and no. of leaves/shoot

\subsection{Data Analysis}

All experiments were laid out in split plot design using 4 replicates. Analysis of variance related to a split plot design experiments as described by Gomez and Gomez, (1984), was conducted. The treatment means were compared by the Least Significant Differences test (LSD) at 0.05 probability level (Steele and Torrie, 1984).

\section{Results and Discussion}

The results revealed obvious significant differences due to effects of lemon cultivars, plant growth regulators combinations and their interactions on in vitro nodal segments of lemon at all measured traits except no. of days to buds sprouting (Table 1).

Table 1. Mean of squares of no. of days to buds sprouting, \% of sprouted buds, \% dead shootlets, average length of primary shoots $(\mathrm{mm})$ and average no. of leaves/shoot as affected by the Interaction between BAP, KIN and 2,4- D combinations and four lemon cultivars cultured in vitro.

\begin{tabular}{|l|c|c|c|c|c|c|}
\hline Source of variance & df & $\begin{array}{c}\text { No. of days to } \\
\text { buds } \\
\text { sprouting }\end{array}$ & $\begin{array}{c}\% \text { of sprouted } \\
\text { buds }\end{array}$ & $\begin{array}{c}\% \text { dead } \\
\text { shootlets }\end{array}$ & $\begin{array}{c}\text { Average length of } \\
\text { primary shoots (mm) }\end{array}$ & $\begin{array}{c}\text { average no. of } \\
\text { leaves/shoot }\end{array}$ \\
\hline Rep. & 2 & 82.171 & 1007.419 & 365.714 & 724.829 & 0.358 \\
\hline Lemon Cultivars (cvs) & 3 & $70.194 \mathrm{~ns}$ & $8034.884 * * *$ & $16278.192 * * *$ & $449.317 * * *$ & $20.964 * * *$ \\
\hline Rep*cvs & 6 & 61.059 & 63.948 & 1040.145 & 82.965 & 0.636 \\
\hline Growth regulators (GRs) & 20 & $247.932 * * *$ & $1853.538 * * *$ & $2926.633^{* * *}$ & $171.224 * * *$ & $3.595 * * *$ \\
\hline cvs* GRs & 60 & $105.394 * * *$ & $1567.872 * * *$ & $2529.105 * * *$ & $73.131 * * *$ & $1.994 * * *$ \\
\hline Error & 160 & 31.324 & 69.676 & 503.521 & 21.228 & 0.482 \\
\hline
\end{tabular}

ns: non significant at $\mathrm{p} \leq 0.05$.

$*, * * * * *$ significant at $\mathrm{p} \leq 0.05,0.01,0.001$. 


\subsection{No. of days to bud sprouting}

There were observed significant interaction between lemon cultivars and the applied growth regulators combinations with regard number of days to bud sprouting. Many interaction treatments caused obvious dilation of bud sprouting i.e. explants of 'Shehri' cultivar on culture medium Kin at $0.5 \mathrm{mgl}^{-1}+2,4-\mathrm{D} 0.5 \mathrm{mgl}^{-1}$ (28.33 days). Also, many explants of different cultivars rapidly sprouted on different culture medium i.e. 'Aln-Eurka' on MS0 (14.33 days) and BAP at $2 \mathrm{mgl}^{-1}+2,4-\mathrm{D}$ at $1 \mathrm{mgl}^{-1}(14.67$ days); 'Shehri' on MS0 (14.67 days), BAP at $0.5 \mathrm{mgl}^{-1}$ (14.00 days) and BAP at $1 \mathrm{mgl}^{-1}+2,4-\mathrm{D}$ $0.5 \mathrm{mgl}^{-1}$ (14.67 days); and 'Shaary' on Kin at $0.5 \mathrm{mg} / 1^{-1}+2,4-\mathrm{D}$ at $1 \mathrm{mgl}^{-1}$ (14.33 days) (Table 2).

There were observed no sprouted buds of explants of 'Shehri' on Kin at 0.5 and $1 \mathrm{mg} \mathrm{l}^{-1}+$
2,4- D at 1 and $0.5 \mathrm{mgl}^{-1}$, 'Shaary' on Kin at 0.5 and $1 \mathrm{mg} \mathrm{l}^{-1}+2,4-\mathrm{D}$ at $1,0.5$ and $1 \mathrm{mgl}^{-1}$, 'Banzahir' on Kin at $1 \mathrm{mgl}^{-1}+2,4-\mathrm{D} 0.5 \mathrm{mgl}^{-1}$ (Table 2). There were reported that the success of citrus in vitro organogenesis is challenged by different factors. The types of culture medium and medium composition were reported to be the most important factors affecting in vitro organogenesis of citrus species (Khan et al., 2009; Rattanpal et al., 2011). Perez-MolpheBalch and Ochoa-Alejo (1997) reported that $33 \pm 3$ $\mu \mathrm{m}$ BA was optimal for regeneration in the apical end of intermodal stem pieces of Citrus aurantifolia and Citrus reticulata. Rattanpal, et al., (2011) illustrated that the regeneration of Citruss spp. were obtained in the presence of BAP alone or in combination with other phytohormones.

Table 2. Number of days to buds sprouting as affected by the Interaction between BAP, KIN and 2,4- D combinations and four lemon (Citrus limon L. Burm) cultivars cultured in vitro.

\begin{tabular}{|c|c|c|c|c|}
\hline \multirow{2}{*}{ Treatments } & \multicolumn{4}{|c|}{ Lemon cultivars } \\
\hline & Aln-Eurka & Banzahir & Shehri & Shaary \\
\hline MS0 & 14.33 & 17.67 & 14.67 & 21.33 \\
\hline \multicolumn{5}{|l|}{ BAP } \\
\hline $0.5 \mathrm{mg} / \mathrm{l}^{-1}$ & 24.00 & 20.67 & 14.00 & 27.66 \\
\hline $1.0 \mathrm{mg} / \mathrm{l}^{-1}$ & 17.70 & 19.33 & 23.70 & 25.70 \\
\hline $1.5 \mathrm{mg} / \mathrm{l}^{-1}$ & 21.33 & 17.33 & 23.67 & 23.66 \\
\hline $2.0 \mathrm{mg} / \mathrm{l}^{-1}$ & 27.00 & 19.00 & 16.67 & 18.00 \\
\hline \multicolumn{5}{|l|}{ Kin } \\
\hline $0.5 \mathrm{mg} / \mathrm{l}^{-1}$ & 16.00 & 24.67 & 17.00 & 18.33 \\
\hline $1.0 \mathrm{mg} / \mathrm{l}^{-1}$ & 18.33 & 19.33 & 26.00 & 26.67 \\
\hline $1.5 \mathrm{mg} / \mathrm{l}^{-1}$ & 18.33 & 23.00 & 15.00 & 27.33 \\
\hline $2.0 \mathrm{mg} / \mathrm{l}^{-1}$ & 23.00 & 23.67 & 20.00 & 23.33 \\
\hline \multicolumn{5}{|l|}{$\mathrm{BAP}+2,4-\mathrm{D}$} \\
\hline $0.5 \mathrm{mg} / \mathrm{l}^{-1}+0.5 \mathrm{mg} / \mathrm{l}^{-1}$ & 22.00 & 25.00 & 26.67 & 26.00 \\
\hline $0.5 \mathrm{mg} / \mathrm{l}^{-1}+1 \mathrm{mg} / \mathrm{l}^{-1}$ & 23.00 & 22.33 & 23.33 & 21.33 \\
\hline $1 \mathrm{mg} / \mathrm{l}^{-1}+0.5 \mathrm{mg} / \mathrm{l}^{-1}$ & 26.67 & 17.33 & 14.67 & 18.33 \\
\hline $1 \mathrm{mg} / \mathrm{l}^{-1}+1 \mathrm{mg} / \mathrm{l}^{-1}$ & 16.00 & 23.00 & 28.00 & 21.00 \\
\hline $2 \mathrm{mg} / \mathrm{l}^{-1}+0.5 \mathrm{mg} / \mathrm{l}^{-1}$ & 23.33 & 18.67 & 14.67 & 26.33 \\
\hline $2 \mathrm{mg} / \mathrm{l}^{-1}+1 \mathrm{mg} / \mathrm{l}^{-1}$ & 14.67 & 19.33 & 26.66 & 13.33 \\
\hline \multicolumn{5}{|l|}{ Kin+2,4-D } \\
\hline $0.5 \mathrm{mg} / \mathrm{l}^{-1}+0.5 \mathrm{mg} / \mathrm{l}^{-1}$ & 22.00 & 16.67 & 28.33 & $0.00^{1^{*}}$ \\
\hline $0.5 \mathrm{mg} / \mathrm{l}^{-1}+1 \mathrm{mg} / \mathrm{l}^{-1}$ & 20.66 & 16.00 & $0.00^{1, *}$ & 14.33 \\
\hline $1 \mathrm{mg} / \mathrm{l}^{-1}+0.5 \mathrm{mg} / \mathrm{l}^{-1}$ & 21.00 & $0.00^{1, *}$ & $0.00^{1, *}$ & $0.00^{1, *}$ \\
\hline $1 \mathrm{mg} / \mathrm{l}^{-1}+1 \mathrm{mg} / \mathrm{l}^{-1}$ & 20.00 & 21.33 & $0.00^{1, *}$ & 17.67 \\
\hline $2 \mathrm{mg} / \mathrm{l}^{-1}+0.5 \mathrm{mg} / \mathrm{l}^{-1}$ & 20.67 & 26.33 & 25.33 & 18.67 \\
\hline $2 \mathrm{mg} / \mathrm{l}^{-1}+1 \mathrm{mg} / \mathrm{l}^{-1}$ & 25.67 & 25.00 & 24.00 & 27.67 \\
\hline $\operatorname{LSD}_{0.05}\left(\mathrm{cvs}^{*} \mathrm{GR}\right)=9$. & & & & \\
\hline
\end{tabular}

\footnotetext{
${ }^{1}$ The data were subjected to transformation using square roots (Gomez and Gomez 1984).

${ }^{*}$ No buds were sprouted.
} 


\subsection{Percentage of sprouted buds}

The percentage of sprouted buds was significantly affected by interaction between lemon cultivars and growth regulators combinations (Table 3). All buds of 'Shehri' explants were sprouted on MS medium supplemented with BAP at $0.5 \mathrm{mg} / \mathrm{l}-1(100 \%$ sprouting). Also, sprouting percentages of $88.88 \%, 88.89 \%$ and $89.01 \%$ were observed for explants of the lemon cultivar 'Shehri" with culture medium MS0, MS + BAP $1 \mathrm{mg} / 1^{-1}$ $+2,4-\mathrm{D} 0.5 \mathrm{mg} / \mathrm{l}^{-1}$ and MS + BAP $2 \mathrm{mg} / \mathrm{l}^{-1}+$ 2,4- D $0.5 \mathrm{mg} / \mathrm{l}^{-1}$, respectively. High percentages of sprouted buds were observed for explants of 'Aln-Eurka' with the culture medium MS0 and MS + BAP $2 \mathrm{mg} / \mathrm{l}^{-1}+2,4-\mathrm{D}$ $1 \mathrm{mg} / \mathrm{l}^{-1}$ (Fig $1 \mathrm{D}$ ). On the other hand, low sprouting percentages were observed for explants of the cultivar 'Shaary' with most of the tested growth regulators combinations obviously on MS + BAP $2 \mathrm{mg} / \mathrm{l}-1$, MS + Kin $0.5 \mathrm{mg} / 1^{-1}$, MS + BAP $1 \mathrm{mg} / 1^{-1}+2,4-\mathrm{D}$ $0.5 \mathrm{mg} / \mathrm{l}^{-1}$ and $\mathrm{MS}+\mathrm{Kin} 2 \mathrm{mg} / \mathrm{l}^{-1}+2,4-\mathrm{D}$ $0.5 \mathrm{mg} / \mathrm{l}^{-1} \quad$ (Table 3 and (Fig 1 B\&C)). Furthermore, the lemon cultivars 'Banziher' and 'Aln-Eurka' registered lower percentages of buds sprouting on culture medium supplemented with BAP $2 \mathrm{mg} / \mathrm{l}^{-1}$ and Kin $1 \mathrm{mg} / \mathrm{l}^{-1}$ for 'Banziher' and $\mathrm{Kin} 2 \mathrm{mg} / \mathrm{l}^{-1}$, BAP $2 \mathrm{mg} / \mathrm{l}^{-1}$ and BAP $1 \mathrm{mg} / \mathrm{l}^{-1}+2,4-\mathrm{D} 0.5 \mathrm{mg} / \mathrm{l}^{-1}$ for 'Aln-Eurka'. Cardoso et al., (2014) evaluated the response of 27 cultivars of Citrus sinensis and of one hybrid C. clementina x C. sinensis, to in vitro anther culture. Ten cultivars of sweet oranges showed embryogenic callus induction, mostly blood sweet oranges cultivars, such as Tarocco, Moro and Sanguinelli. Shawkat and Bushra (2006) studied the effect of various concentrations and combinations of 2,4-dichlorophenoxyacetic acid (2,4-D), 6-benzylaminopurine (BAP) and Naphthalene acetic acid (NAA) on regeneration of rough lemon (Citrus jambhiri Lush.) explants. They observed maximum shoot regeneration response $(70 \%)$ from callus on MS medium supplemented with BA $3 \mathrm{mg}$ $\mathrm{L}^{-1}$. Kour and Singh (2012) reported that the in vitro multiplication of Rough Lemon (Citrus jambhiri Lush.) on MS medium supplemented with BAP $(1.5 \mathrm{mg} / \mathrm{L})$ and malt extract 500 $\mathrm{mg} / \mathrm{L}$ resulted in maximum culture establishment, number of shoots and length of longest shoot per culture in minimum time during shoot proliferation.

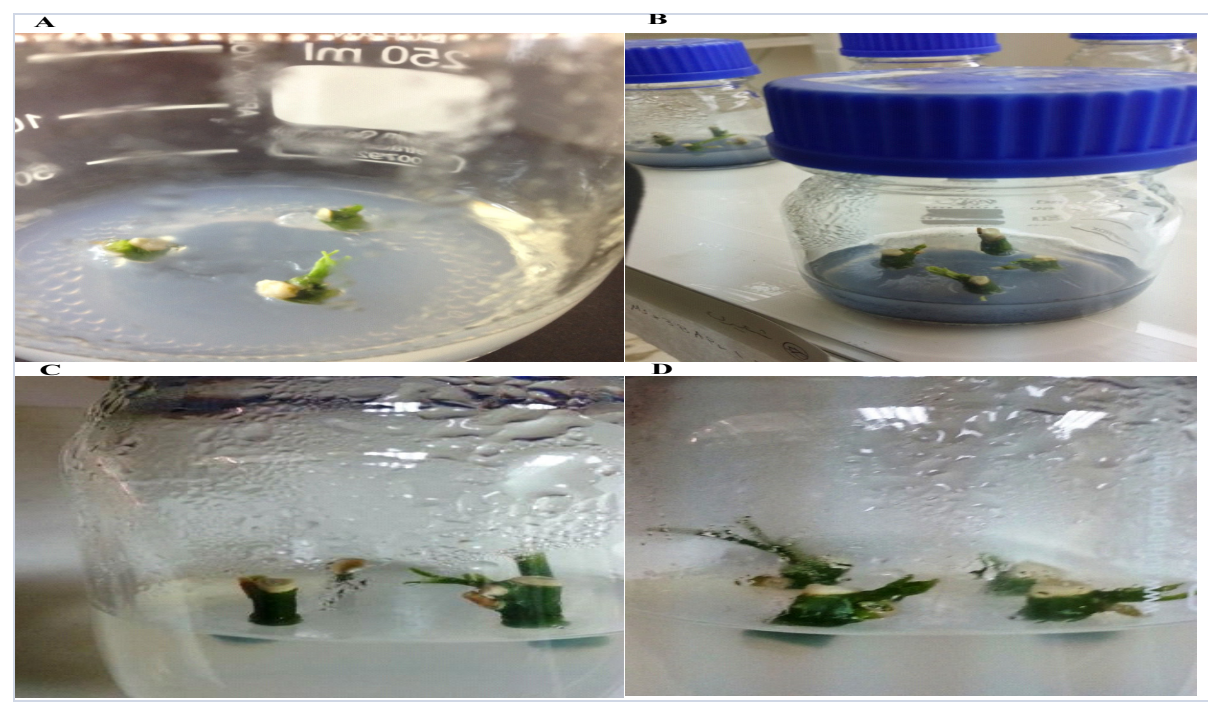

Fig. 1. Response of four Lemon (Citrus limon L. Burm) cultivars cultured in vitro to BAP, Kin and 2,4- D combinations: A and $B$ ) high percentages of sprouted of buds, C) low percentage of bud sprouting and D) performing shoots and leaves. 
Table 3. Percentage of sprouted buds as affected by the Interaction between BAP, KIN and 2,4- D combinations and four lemon (Citrus limon L. Burm) cultivars cultured in vitro.

\begin{tabular}{|c|c|c|c|c|}
\hline \multirow{2}{*}{ Treatments } & \multicolumn{4}{|c|}{ Lemon cultivars } \\
\hline & Aln-Eurka & Banzahir & Shehri & Shaary \\
\hline MS0 & 89.01 & 58.33 & 88.86 & 55.57 \\
\hline \multicolumn{5}{|l|}{ BAP } \\
\hline $0.5 \mathrm{mg} / \mathrm{l}^{-1}$ & 38.87 & 44.43 & 100.00 & 16.66 \\
\hline $1.0 \mathrm{mg} / \mathrm{l}^{-1}$ & 61.14 & 52.80 & 38.87 & 16.76 \\
\hline $1.5 \mathrm{mg} / \mathrm{l}^{-1}$ & 44.43 & 66.70 & 33.30 & 38.87 \\
\hline $2.0 \mathrm{mg} / \mathrm{l}^{-1}$ & 16.67 & 5.57 & 61.13 & 5.56 \\
\hline \multicolumn{5}{|l|}{ Kin } \\
\hline $0.5 \mathrm{mg} / \mathrm{l}^{-1}$ & 72.23 & 38.87 & 61.13 & 5.60 \\
\hline $1.0 \mathrm{mg} / \mathrm{l}^{-1}$ & 66.70 & 5.50 & 38.86 & 27.77 \\
\hline $1.5 \mathrm{mg} / \mathrm{l}^{-1}$ & 5.70 & 38.90 & 69.90 & 16.67 \\
\hline $2.0 \mathrm{mg} / \mathrm{l}^{-1}$ & 38.87 & 38.77 & 66.70 & 38.87 \\
\hline \multicolumn{5}{|l|}{$\mathrm{BAP}+2,4-\mathrm{D}$} \\
\hline $0.5 \mathrm{mg} / \mathrm{l}^{-1}+0.5 \mathrm{mg} / \mathrm{l}^{-1}$ & 38.90 & 38.87 & 38.78 & 16.70 \\
\hline $0.5 \mathrm{mg} / \mathrm{l}^{-1}+1 \mathrm{mg} / \mathrm{l}^{-1}$ & 33.30 & 38.67 & 38.90 & 44.43 \\
\hline $1 \mathrm{mg} / \mathrm{l}^{-1}+0.5 \mathrm{mg} / \mathrm{l}^{-1}$ & 16.60 & 61.33 & 88.89 & 5.57 \\
\hline $1 \mathrm{mg} / \mathrm{l}^{-1}+1 \mathrm{mg} / \mathrm{l}^{-1}$ & 72.23 & 44.43 & 7.60 & 50.00 \\
\hline $2 \mathrm{mg} / \mathrm{l}^{-1}+0.5 \mathrm{mg} / \mathrm{l}^{-1}$ & 27.77 & 55.60 & 89.00 & 16.67 \\
\hline $2 \mathrm{mg} / \mathrm{l}^{-1}+1 \mathrm{mg} / \mathrm{l}^{-1}$ & 88.88 & 55.57 & 11.10 & 33.33 \\
\hline \multicolumn{5}{|l|}{ Kin+2,4-D } \\
\hline $0.5 \mathrm{mg} / \mathrm{l}^{-1}+0.5 \mathrm{mg} / \mathrm{l}^{-1}$ & 44.40 & 58.33 & 16.67 & $0.00^{1,{ }^{*}}$ \\
\hline $0.5 \mathrm{mg} / \mathrm{l}^{-1}+1 \mathrm{mg} / \mathrm{l}^{-1}$ & 50.00 & 72.23 & $0.00^{1,{ }^{*}}$ & 33.33 \\
\hline $1 \mathrm{mg} / \mathrm{l}^{-1}+0.5 \mathrm{mg} / \mathrm{l}^{-1}$ & 50.00 & $0.00^{1, *}$ & $0.00^{1, *}$ & $0.00^{1,{ }^{*}}$ \\
\hline $1 \mathrm{mg} / \mathrm{l}^{-1}+1 \mathrm{mg} / \mathrm{l}^{-1}$ & 50.00 & 41.00 & $0.00^{1, *}$ & 11.10 \\
\hline $2 \mathrm{mg} / \mathrm{l}^{-1}+0.5 \mathrm{mg} / \mathrm{l}^{-1}$ & 50.00 & 25.00 & 38.87 & 5.60 \\
\hline $2 \mathrm{mg} / \mathrm{l}^{-1}+1 \mathrm{mg} / \mathrm{l}^{-1}$ & 27.77 & 31.30 & 35.37 & 22.20 \\
\hline
\end{tabular}

${ }^{1}$ The data were subjected to transformation using square roots (Gomez and Gomez 1984).

* No buds were sprouted.
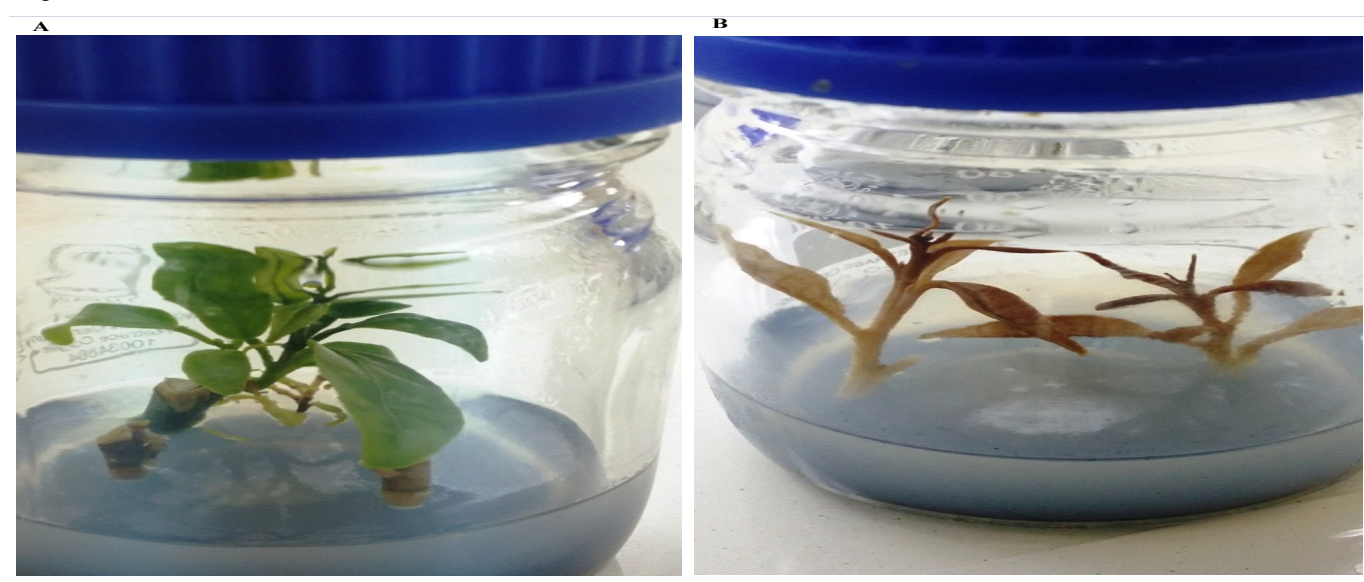

Fig. 2. Response of four lemon cultivars cultured in vitro on different BAP, Kin and 2,4- D combinations: A) Length of primeray shoots and no. of leaves/shoot, and B) \% of dead shootlets. 
Table 4. percentage of dead shootlets after bud sprouting as affected by the Interaction between BAP, KIN and 2,4- D combinations and four lemon cultivars cultured in vitro.

\begin{tabular}{|c|c|c|c|c|}
\hline \multirow{2}{*}{ Treatments } & \multicolumn{4}{|c|}{ Lemon cultivars } \\
\hline & Aln-Eurka & Banzahir & Shehri & Shaary \\
\hline MS0 & 56.31 & 9.26 & 82.64 & 41.11 \\
\hline \multicolumn{5}{|l|}{ BAP } \\
\hline $0.5 \mathrm{mg} / \mathrm{l}^{-1}$ & 86.90 & $0.00^{1}$ & 77.78 & $0.00^{1}$ \\
\hline $1.0 \mathrm{mg} / \mathrm{l}^{-1}$ & 82.83 & 67.50 & 86.90 & 0.00 \\
\hline $1.5 \mathrm{mg} / \mathrm{l}^{-1}$ & 89.17 & 91.11 & 16.67 & 15.87 \\
\hline $2.0 \mathrm{mg} / \mathrm{l}^{-1}$ & 100.00 & 66.67 & 54.85 & 0.00 \\
\hline \multicolumn{5}{|l|}{ Kin } \\
\hline $0.5 \mathrm{mg} / \mathrm{l}^{-1}$ & 77.23 & 0.00 & 54.85 & 0.00 \\
\hline $1.0 \mathrm{mg} / \mathrm{l}^{-1}$ & 83.33 & 66.67 & 86.90 & 23.33 \\
\hline $1.5 \mathrm{mg} / \mathrm{l}^{-1}$ & 66.67 & 72.22 & 50.53 & 27.77 \\
\hline $2.0 \mathrm{mg} / \mathrm{l}^{-1}$ & 15.87 & 72.22 & 34.00 & 29.00 \\
\hline \multicolumn{5}{|l|}{$\mathrm{BAP}+2,4-\mathrm{D}$} \\
\hline $0.5 \mathrm{mg} / \mathrm{l}^{-1}+0.5 \mathrm{mg} / \mathrm{l}^{-1}$ & 77.59 & 100.00 & 13.09 & 27.77 \\
\hline $0.5 \mathrm{mg} / \mathrm{l}^{-1}+1 \mathrm{mg} / \mathrm{l}^{-1}$ & 0.00 & 27.78 & 28.98 & 26.11 \\
\hline $1 \mathrm{mg} / \mathrm{l}^{-1}+0.5 \mathrm{mg} / \mathrm{l}^{-1}$ & 100.00 & 62.50 & 43.68 & 0.00 \\
\hline $1 \mathrm{mg} / \mathrm{l}^{-1}+1 \mathrm{mg} / \mathrm{l}^{-1}$ & 8.12 & 0.00 & 50.00 & 33.33 \\
\hline $2 \mathrm{mg} / \mathrm{l}^{-1}+0.5 \mathrm{mg} / \mathrm{l}^{-1}$ & 100.00 & 62.14 & 43.68 & 27.77 \\
\hline $2 \mathrm{mg} / \mathrm{l}^{-1}+1 \mathrm{mg} / \mathrm{l}^{-1}$ & 43.68 & 66.14 & 100.00 & 62.96 \\
\hline \multicolumn{5}{|l|}{ Kin+2,4-D } \\
\hline $0.5 \mathrm{mg} / \mathrm{l}^{-1}+0.5 \mathrm{mg} / \mathrm{l}^{-1}$ & 87.50 & 81.48 & 44.44 & $0.00^{2, *}$ \\
\hline $0.5 \mathrm{mg} / \mathrm{l}^{-1}+1 \mathrm{mg} / \mathrm{l}^{-1}$ & 56.85 & 23.38 & $0.00^{2, *}$ & 44.44 \\
\hline $1 \mathrm{mg} / \mathrm{l}^{-1}+0.5 \mathrm{mg} / \mathrm{l}^{-1}$ & 67.22 & $0.00^{2, *}$ & $0.00^{2, *}$ & 66.67 \\
\hline $1 \mathrm{mg} / \mathrm{l}^{-1}+1 \mathrm{mg} / \mathrm{l}^{-1}$ & 67.22 & $0.00^{2, *}$ & $0.00^{2, *}$ & 50.00 \\
\hline $2 \mathrm{mg} / \mathrm{l}^{-1}+0.5 \mathrm{mg} / \mathrm{l}^{-1}$ & 67.22 & 19.44 & 13.10 & 0.00 \\
\hline $2 \mathrm{mg} / \mathrm{l}^{-1}+1 \mathrm{mg} / \mathrm{l}^{-1}$ & 53.33 & 18.63 & 16.02 & 25.00 \\
\hline
\end{tabular}

\footnotetext{
${ }^{1}$ The data were subjected to transformation using square roots (Gomez and Gomez 1984).

${ }^{2}$ No buds were sprouted.

* Treatments were excluded from further analysis.
} 


\subsection{Percentage of dead shootlets after bud sprouting}

Regarding interaction the results illustrated that there were no dead shootlets after sprouting of all cultured explants of the lemon cultivar 'Shaary' on culture medium contained BAP at 0.5 and $1 \mathrm{mgl}^{-1}, \mathrm{KIN}$ at $0.5 \mathrm{mgl}^{-1}$, BAP $1 \mathrm{mgl}^{-1}+2,4-\mathrm{D} 0.5 \mathrm{mgl}^{-1}$, and KIN $2 \mathrm{mgl}^{-1}+$ 2,4- D $0.5 \mathrm{mgl}^{-1}$. Also, there were no observed dead shootlest after sprouting for explants of 'Aln-Eurka' on MS medium supplemented with $0.5 \mathrm{mgl}^{-1}$ BAP $+1 \mathrm{mgl}^{-1}$ 2,4- D and 'Banziher' on MS medium contained $1 \mathrm{mg} / \mathrm{l}-1$ BAP, $1 \mathrm{mg} / \mathrm{l}-1 \mathrm{KIN}, 1 \mathrm{mg} / \mathrm{l}-1$ BAP + 1mg/l-1 2,4- D and $1 \mathrm{mg} / \mathrm{l}-1 \mathrm{KIN}+1 \mathrm{mg} / \mathrm{l}-1$ 2,4- D (Table 4). On the other hand, all formed shooltes on explants cultured in vitro of the lemon cultivars 'Aln-Eurka' (MS+ 2mg/l-1 $\mathrm{BAP}, \mathrm{MS}+1 \mathrm{mg} / \mathrm{l}-1 \mathrm{BAP}+0.5 \mathrm{mg} / \mathrm{l}-1$ 2,4- D and $\left.\mathrm{MS}+2 \mathrm{mgl}^{-1} \mathrm{BAP}+0.5 \mathrm{mgl}^{-1} 2,4-\mathrm{D}\right)$, 'Banziher' (MS $+0.5 \mathrm{mgl}^{-1} \mathrm{BAP}+0.5 \mathrm{mgl}^{-1}$ 2,4- D) and 'Shehri' (MS + $1 \mathrm{mgl}^{-1}$ BAP + $0.5 \mathrm{mgl}^{-1}$ 2,4- D). Bordon et al., (2000) investigated the effects of genotype on the morphogenic response in vitro of epicotyl segments of citrus rootstocks. They compared the responses to in vitro morphogenic response of four Citrus species ( $C$. aurantium, $C$. macrophylla, C. reshni and C. sinensis) and the hybrid Troyer citrange $(C$. sinensis Poncirus trifoliata). The authors found that the pathway of the apical end of the explants planted vertically was not significant differed between the tested cultivars. However, they reported that the number of differentiated buds/responsive explant was higher in Cleopatra mandarin and sweet orange than in sour orange. In addition, they observed that the explants planted vertically revealed qualitative and quantitative deference in morphogenesis at the basal end.

\subsection{Average length of primary shoot (mm)}

Regarding interaction, the results illustrated that 18 interaction treatments produced highest primary shoots and 21 interaction treatments produced shortest primary shoots with no significant differences (Table 5). Explants of the 'Euraka' cultivar formed high length of primary shoots on 7 different culture medium with compared to 4, 3, 4 culture medium for 'Banziher', Shehri' and 'Shaary', respectively. Oppositely, short primary shoots were produced by explants of 'Banziher' on 9 different culture medium as compared to 2, 6 and 5 culture medium for explants of 'AlnEurka', 'Shaary' and 'Shehri' (Table 5). The culture medium with BAP at $1 \mathrm{mg} / 1-1+2,4-\mathrm{D}$ at $1 \mathrm{mg} / 1^{-1}$ produced primary shoots of $25.4 \mathrm{~mm}$ length of 'Sherhi' cultivar, while the same medium composition produced dwarf primary shoots $(4.5 \mathrm{~mm})$ with explants of 'Aln-Eurka'. Haripyaree et al., (2011) reported that the shoot tip explants of Citrus megaloxycarpa produced multiple shoot buds when cultured on MS medium containing 0.25 to $2 \mathrm{mg} \mathrm{L}^{-1} \mathrm{~N} 6$ benzyl adenine (BA) alone, and in combination with $0.50 \mathrm{mg} \mathrm{L}^{-1}$ naphthalene acetic acid (NAA) or with 0.50 mg L ${ }^{-1}$ Kinetin. Mng'omba, et al., (2007) found that MS media supplemented with 2.0 $\mathrm{mg} / \mathrm{L}$ benzylaminopurine (BAP) was superior in the number of micro-shoots produced for jacket plum (Pappea capensis). A high frequency (66-100\%) of shoot regeneration was obtained from shoot tip and nodal stem segments of mature plants cultured on medium with or without benzylaminopurine (BAP) (Sim, et al., 1989). Shoot formation has been reported as a result of direct morphogenesis or from regeneration from callus tissue formed from the primary explants (Perez-MolpheBalch and Ochoa-Alejo, 1997). 
Table 5. Average length of primary shoots $(\mathrm{mm})$ as affected by the Interaction between BAP, KIN and 2,4- D combinations and four lemon cultivars cultured in vitro.

\begin{tabular}{|c|c|c|c|c|}
\hline \multirow[t]{2}{*}{ Treatments } & \multicolumn{4}{|c|}{ Lemon cultivars } \\
\hline & Aln-Eurka & Banzahir & Shehri & Shaary \\
\hline MS0 & 24.63 & 19.17 & 8.40 & 19.30 \\
\hline \multicolumn{5}{|l|}{ BAP } \\
\hline $0.5 \mathrm{mg} / \mathrm{l}^{-1}$ & 22.00 & 20.63 & 21.27 & 15.00 \\
\hline $1.0 \mathrm{mg} / \mathrm{l}^{-1}$ & 13.50 & 12.33 & 15.43 & 12.77 \\
\hline $1.5 \mathrm{mg} / \mathrm{l}^{-1}$ & 15.90 & 12.50 & 12.33 & 14.26 \\
\hline $2.0 \mathrm{mg} / \mathrm{l}^{-1}$ & 17.50 & 9.50 & 14.17 & 7.50 \\
\hline \multicolumn{5}{|l|}{ Kin } \\
\hline $0.5 \mathrm{mg} / \mathrm{l}^{-1}$ & 15.20 & 16.27 & 14.60 & 7.51 \\
\hline $1.0 \mathrm{mg} / \mathrm{l}^{-1}$ & 24.30 & 8.51 & 10.00 & 15.02 \\
\hline $1.5 \mathrm{mg} / \mathrm{l}^{-1}$ & 9.50 & 7.50 & 17.80 & 15.00 \\
\hline $2.0 \mathrm{mg} / \mathrm{l}^{-1}$ & 22.26 & 10.50 & 17.26 & 20.33 \\
\hline \multicolumn{5}{|l|}{ BAP+2,4-D } \\
\hline $0.5 \mathrm{mg} / \mathrm{l}^{-1}+0.5 \mathrm{mg} / \mathrm{l}^{-1}$ & 15.36 & 10.13 & 13.76 & 13.76 \\
\hline $0.5 \mathrm{mg} / \mathrm{l}^{-1}+1 \mathrm{mg} / \mathrm{l}^{-1}$ & 18.50 & 19.26 & 12.26 & 18.40 \\
\hline $1 \mathrm{mg} / \mathrm{l}^{-1}+0.5 \mathrm{mg} / \mathrm{l}^{-1}$ & 15.50 & 13.66 & 25.40 & 8.00 \\
\hline $1 \mathrm{mg} / \mathrm{l}^{-1}+1 \mathrm{mg} / \mathrm{l}^{-1}$ & 16.53 & 4.50 & 11.50 & 20.00 \\
\hline $2 \mathrm{mg} / \mathrm{l}^{-1}+0.5 \mathrm{mg} / \mathrm{l}^{-1}$ & 8.76 & 19.13 & 20.16 & 16.00 \\
\hline $2 \mathrm{mg} / \mathrm{l}^{-1}+1 \mathrm{mg} / \mathrm{l}^{-1}$ & 14.40 & 8.76 & 8.50 & 12.26 \\
\hline \multicolumn{5}{|l|}{ Kin+2,4-D } \\
\hline $0.5 \mathrm{mg} / \mathrm{l}^{-1}+0.5 \mathrm{mg} / \mathrm{l}^{-1}$ & 22.63 & 7.50 & 7.50 & $0.00^{1,2^{*}}$ \\
\hline $0.5 \mathrm{mg} / \mathrm{l}^{-1}+1 \mathrm{mg} / \mathrm{l}^{-1}$ & 18.33 & 13.30 & $0.00^{1,2^{*}}$ & 11.80 \\
\hline $1 \mathrm{mg} / \mathrm{l}^{-1}+0.5 \mathrm{mg} / \mathrm{l}^{-1}$ & 14.50 & $0.00^{1,2^{*}}$ & $0.0,0^{1,2^{*}}$ & $0.00^{1,2^{*}}$ \\
\hline $1 \mathrm{mg} / \mathrm{l}^{-1}+1 \mathrm{mg} / \mathrm{l}^{-1}$ & 16.50 & 8.00 & $0.00^{1,2^{*}}$ & 5.00 \\
\hline $2 \mathrm{mg} / \mathrm{l}^{-1}+0.5 \mathrm{mg} / \mathrm{l}^{-1}$ & 18.00 & 15.26 & 14.50 & 7.50 \\
\hline $2 \mathrm{mg} / \mathrm{l}^{-1}+1 \mathrm{mg} / \mathrm{l}^{-1}$ & 24.16 & 16.20 & 13.40 & 17.00 \\
\hline
\end{tabular}

${ }^{1}$ The data were subjected to transformation using square roots (Gomez and Gomez 1984)

${ }^{2}$ No buds were sprouted

* Treatments were excluded from further analysis

\subsection{Average number of leaves/shoot}

About the interaction between the applied growth regulators and lemon cultivars the results were presented in Table (6). It is quite clear that 'Aln-Eurka' cultivar showed high performance with regard no. of leaves/shoot on 9 culture medium complemented with different growth regulators combinations. Moreover, adding a combination of BAP at $0.5 \mathrm{mg} / \mathrm{l}^{-1}+2,4-\mathrm{D}$ at $1 \mathrm{mg} / \mathrm{l}^{-1}$ to the culture medium enhanced explants of the cultivar 'Eruka' to produce maximum no of leaves/shoot (4.0). Contrary, shoots of "Aln-
Eurka' explants were inhibited to produce leaves on culture medium with 12,8 and 8 different growth regulators combinations reflecting their inferior response to growth regulators. Only, 0.5 leaves/shoot was observed when explants of 'Banziher', 'Shehri' and 'Shaary' cultivars cultured on MS medium complemented with BAP at $2 \mathrm{mg} / \mathrm{l}^{-1}$, BAP at $1.5 \mathrm{mg} / 1^{-1}$ and BAP at $2 \mathrm{mg} / 1^{-1}$, respectively (Table 6). Cardosoet al., (2016) studied the gametic and somatic embryogenesis through in vitro anther culture of different citrus cultivars. They harvested flower buds of different citrus cultivars 
including: blood sweet oranges, clementines, C. sinensis cv. Moro, sweet oranges Tarocco Meli, Tarocco TDV, Tarocco S. Alfio, and $C$. clementina cvs. Corsica and Hernandina. The flower buds were harvest at different times. The researchers found strong influence of the genotype on the type of response that can be obtained from in vitro-cultured anthers for all registered parameters (undeveloped anthers, swollen anthers, anthers with a callus and with an embryogenic callus or with embryos).

Table 6. Average no. of leaves/shoot as affected by the Interaction between BAP, KIN and 2,4- D combinations and four lemon cultivars cultured in vitro.

\begin{tabular}{|c|c|c|c|c|}
\hline \multirow[t]{2}{*}{ Treatments } & \multicolumn{4}{|c|}{ Lemon cultivars } \\
\hline & Aln-Eurka & Banzahir & Shehri & Shaary \\
\hline MS0 & 3.86 & 1.83 & 1.50 & 1.36 \\
\hline \multicolumn{5}{|l|}{ BAP } \\
\hline $0.5 \mathrm{mg} / \mathrm{l}^{-1}$ & 3.50 & 2.80 & 2.00 & 2.00 \\
\hline $1.0 \mathrm{mg} / \mathrm{l}^{-1}$ & 2.10 & 1.50 & 2.16 & 1.50 \\
\hline $1.5 \mathrm{mg} / \mathrm{l}^{-1}$ & 2.20 & 1.50 & 1.16 & 1.76 \\
\hline $2.0 \mathrm{mg} / \mathrm{l}^{-1}$ & 3.00 & 0.50 & 2.26 & 0.50 \\
\hline \multicolumn{5}{|l|}{ Kin } \\
\hline $0.5 \mathrm{mg} / \mathrm{l}^{-1}$ & 3.36 & 2.66 & 2.00 & 1.00 \\
\hline $1.0 \mathrm{mg} / \mathrm{l}^{-1}$ & 3.56 & 1.00 & 2.00 & 1.66 \\
\hline $1.5 \mathrm{mg} / \mathrm{l}^{-1}$ & 0.50 & 0.60 & 2.36 & 1.50 \\
\hline $2.0 \mathrm{mg} / \mathrm{l}^{-1}$ & 3.16 & 0.60 & 1.90 & 1.50 \\
\hline \multicolumn{5}{|l|}{ BAP+2,4-D } \\
\hline $0.5 \mathrm{mg} / \mathrm{l}^{-1}+0.5 \mathrm{mg} / \mathrm{l}^{-1}$ & 1.30 & 1.00 & 2.16 & 1.76 \\
\hline $0.5 \mathrm{mg} / \mathrm{l}^{-1}+1 \mathrm{mg} / \mathrm{l}^{-1}$ & 4.00 & 3.60 & 1.26 & 2.26 \\
\hline $1 \mathrm{mg} / \mathrm{l}^{-1}+0.5 \mathrm{mg} / \mathrm{l}^{-1}$ & 2.50 & 2.16 & 2.80 & 1.00 \\
\hline $1 \mathrm{mg} / \mathrm{l}^{-1}+1 \mathrm{mg} / \mathrm{l}^{-1}$ & 3.36 & 2.20 & 1.50 & 2.00 \\
\hline $2 \mathrm{mg} / \mathrm{l}^{-1}+0.5 \mathrm{mg} / \mathrm{l}^{-1}$ & 0.56 & 2.26 & 2.80 & 1.00 \\
\hline $2 \mathrm{mg} / \mathrm{l}^{-1}+1 \mathrm{mg} / \mathrm{l}^{-1}$ & 2.80 & 0.63 & 0.50 & 1.76 \\
\hline \multicolumn{5}{|l|}{ Kin+2,4-D } \\
\hline $0.5 \mathrm{mg} / \mathrm{l}^{-1}+0.5 \mathrm{mg} / \mathrm{l}^{-1}$ & 2.40 & 1.00 & 0.50 & $0.00^{1,2^{*}}$ \\
\hline $0.5 \mathrm{mg} / \mathrm{l}^{-1}+1 \mathrm{mg} / \mathrm{l}^{-1}$ & 2.50 & 1.76 & $0.00^{1,2^{*}}$ & 1.50 \\
\hline $1 \mathrm{mg} / \mathrm{l}^{-1}+0.5 \mathrm{mg} / \mathrm{l}^{-1}$ & 1.60 & $0.00^{1,2^{*}}$ & $0.00^{1,2^{*}}$ & $0.00^{1,2^{*}}$ \\
\hline $1 \mathrm{mg} / \mathrm{l}^{-1}+1 \mathrm{mg} / \mathrm{l}^{-1}$ & 3.83 & 0.76 & $0.00^{1,2^{*}}$ & 0.56 \\
\hline $2 \mathrm{mg} / \mathrm{l}^{-1}+0.5 \mathrm{mg} / \mathrm{l}^{-1}$ & 2.10 & 2.50 & 1.16 & 1.00 \\
\hline $2 \mathrm{mg} / \mathrm{l}^{-1}+1 \mathrm{mg} / \mathrm{l}^{-1}$ & 1.80 & 2.00 & 1.30 & 1.56 \\
\hline
\end{tabular}

${ }^{1}$ The data were subjected to transformation using square roots (Gomez and Gomez 1984).

${ }^{2}$ No buds were sprouted.

* Treatments were excluded from further analysis.

\section{Conclusion}

Utilizing BAP and 2,4- D in combinations at low concentrations enhanced shoot inductions and formation of tested lemon cultivars. Adding Kin alone or in combinations with 2,4- D at high concentrations delayed bud sprouting and therefore shoot induction and formation of most of tested lemon cultivars. Lemon explants can be successfully in vitro propagated using intermodal segments and 
combinations of BAP, Kin and 2,4- D at low concentrations.

\section{Acknowledgement}

This project was funded by King Abdulaziz City for Science and Technology (KACST) under grant no. (PS-39-13). The authors, therefore, acknowledge with thanks King Abdulaziz City for Science and Technology (KACST) for the generous and full financial support for the research experiment.

\section{References}

Al-Taha, H.A.A. (2009) The use of plant tissue culture technique in micropropagation of salt tolerant plants of local orange trees (Citrus sinensis (L.) Osbeck. cv. Local Orange). Ph.D. Thesis. Agriculture College, Basrah University, Basrah, Iraq, p.192.

Bordón, Y., Guardiola, J.L. and Garcia-Luis, A. (2000) Genotype affects the morphogenic response in vitro of epicotyls segments of Citrus rootstocks, Ann. Bot., 86: 159-166.

Gomez, K.A. and Gomez, A.A. (1984) Statistical Procedures for Agricultural Research, $2^{\text {nd }}$ edition, John Wiley and Sons, New York, p.680.

Grosser, J.W., Ananthakrishnan, G., Calovic, M., Serrano, P., Chandler, J.L., Gmitter, Jr., F.G. and Guo, W.W. (2007) Applications of Somatic Hybridization and Cybridization in Scion and Rootstock Improvement, With Focus on Citrus, Acta Hort. (ISHS) 738: 73-81.

Jajoo, A. (2010) In vitro propagation of Citrus limonia Osbeck. Through nucellar embryo culture, Curr. Res. J. Bio. Sci., 2 (1): 6-8.

Khan, E.U., FU, X.Z., Wang, J., Fan, Q.J., Huang, X.S., Zhang, G.N., Shi, J. and Liu, J.H. (2009) Regeneration and characterization of plants derived from leaf in vitro culture of two sweet orange (Citrus sinensis (L.) Osbeck) cultivars, Scientia Horticulturae, Amsterdam, 120: 70-76.
Kour, K. and Singh, B. (2012) In vitro multiplication of rough lemon (Citrus jambhiri Lush.), IOSR Journal of Agriculture and Veterinary Science (IOSR-JAVS), 1 (4): 59.

Lombardo, M.V., Ashwin, E., Auyeung, B., Chakrabarti, B., Taylor, K., Hackett, G., Bullmore, E.T. and BaronCohen, S. (2012) Fetal testosteroneinfluences sexually dimorphic gray matterin the human brain, J. Neurosci, 32: 674-680.

Ministry of Agriculture (2014) Agriculture statistical year book, Agricultural Research and Development Affairs, Department of Studies, Planning \& Statistics, Riyadh, Saudi Arabia.

Montoliu, L., Roy, R., Regales, L. and Garcia-Diaz, A. (2009) Design of vectors for transgene expression: the use of genomic comparative approache, Comp Immunol Microbiol Infect Dis., 32: 81-90.

Nehra, S.A. and Kartha, K.K. (1994) Meristem and shoot tip culture: Requirements and applications, In: Plant cell and tissue culture, Vasil, I. and Thorpe, T.A. (Eds.) Dordrecht, Netherlands: Kluwer Academic Publishers, pp: 37-70.

Perez-Molphe-Balch, E. and Ochoa-Alejo, N. (1997) In vitro plant regeneration of Mexican lime and mandarin by direct organogenesis, HortSci., 32: 931-934.

Rattanpal, H.S., Kaur, G. and Gupta, M. (2011) In vitro plant regeneration in rough lemon (Citrusjambhiri Lush.) by direct organogenesis, Afr. J. Biotech., 10 (63): 1372413728.

Shawkat, A. and Bushra, M. (2006) Micropropagation of rough lemon (Citrus jambhiri Lush.): Effect of explants type and hormone concentration, Acta Bot. Croat., 65 (2): 137-146.

Shiyab, S. M., Shibli, R. A. and Mohammed, M. M. (2003) Influence of sodium chloride saltstress on growth and nutrient acquisition of sour orange in vitro, Journal of Plant Nutrition, 26: 985-996.

Sim, G.E., Goh, C.J. and Loh, C.S. (1989) Micropropagation of Citrus mitis Blanco - Multiple bud formation from shoot and root explants in the presence $f$ 6Benzylaminopurine, Plant Sci., 59: 203-210. 
استجابة أربعة أصناف من الليمون للإكثار الاقيق باستخدام توليفات من

(BAP, Kin, 2.4-D)

\section{عبدالمحسن ردة السيد، ومجدي علي موسى، وأحمد عبدالله باخثوين

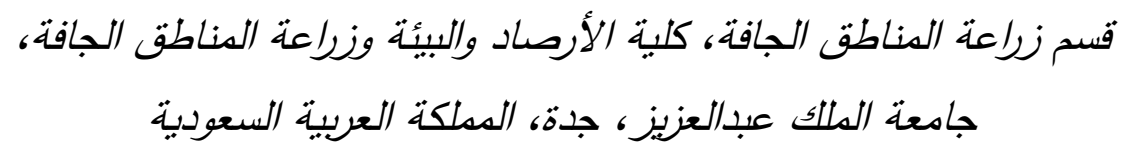

المستخلص. أجريت هذه الدراسة بمعل زراعة الأنجة النباتية بجامعة الملك عبدالعزيز . وذلك لاختبار استجابة أربعة أصناف من الليمون للإكثار الدقيق باستخدام توليفات من (BAP, Kin, 2.4-D). الأجزاء النباتية المستخدمة في هذه الدراسة هي القطع الساقية، والتي جمعت من شتلات ليمون عمرها عام واحد. والتي تم الحصول عليها من مركز دراسات الليمون بنجران، المملكة العربية السعودية. وتم تتفيذ التجربة

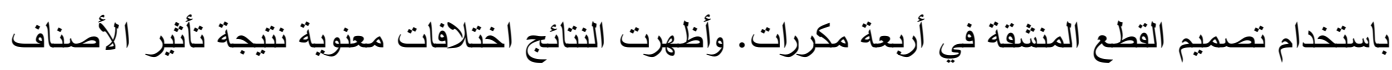

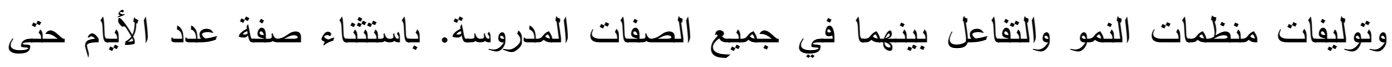
انبثاق البراعم. وأظهرت النتائج أيضًا أن أجزاء نباتية من الصنف الثهري سجلت أعلى القيم فيما يخص

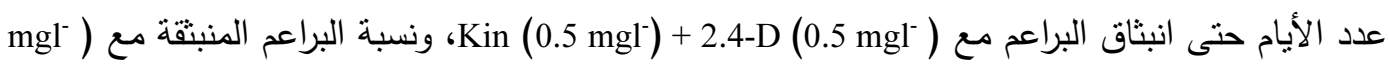

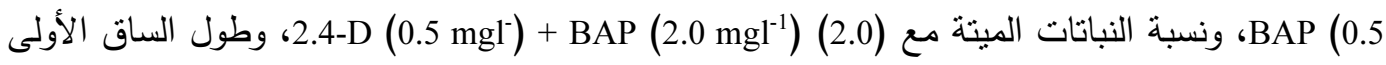
مع (0.5 (0.5 mgl) + BAP (1.0 mgl) وسجلت السيقان المتكونة من صنف الثهري أعلى عدد من

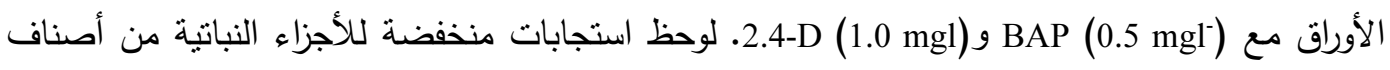
(الثعيري والبنزهير والألن يوريكا) على البيئات المغذية التي احتوت على تركيزات مرتفعة من (BAP)

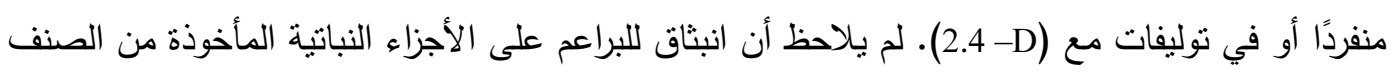

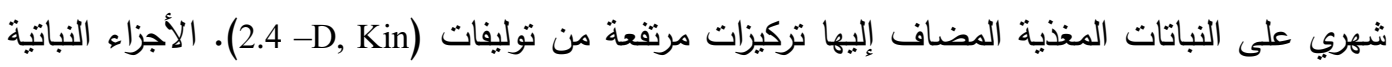
من الليمون يمكن نجاح الإكثار الدقيق لها باستخدام القطع الساقية الصغيرة وتركيزات منخفضة من نوليفات .(BAP,Kin,2.4-D) 